\title{
บusisersaly
}

\section{Soil chemical and fertilizer influences on soluble and medium-sized colloidal phosphorus in agricultural soils}

Fresne, M., Jordan, P., Fenton, O., Mellander, P-E., \& Daly, K. (2021). Soil chemical and fertilizer influences on soluble and medium-sized colloidal phosphorus in agricultural soils. Science of the Total Environment, 754, [142112]. https://doi.org/10.1016/j.scitotenv.2020.142112

Link to publication record in Ulster University Research Portal

\section{Published in:}

Science of the Total Environment

Publication Status:

Published (in print/issue): 01/02/2021

DOI:

10.1016/j.scitotenv.2020.142112

\section{Document Version}

Publisher's PDF, also known as Version of record

\section{General rights}

Copyright for the publications made accessible via Ulster University's Research Portal is retained by the author(s) and / or other copyright owners and it is a condition of accessing these publications that users recognise and abide by the legal requirements associated with these rights.

\section{Take down policy}

The Research Portal is Ulster University's institutional repository that provides access to Ulster's research outputs. Every effort has been made to ensure that content in the Research Portal does not infringe any person's rights, or applicable UK laws. If you discover content in the Research Portal that you believe breaches copyright or violates any law, please contact pure-support@ulster.ac.uk. 


\title{
Soil chemical and fertilizer influences on soluble and medium-sized colloidal phosphorus in agricultural soils
}

\author{
Maëlle Fresne ${ }^{\mathrm{a}, \mathrm{b}, \mathrm{c}, *}$, Phil Jordan $^{\mathrm{c}}$, Owen Fenton ${ }^{\mathrm{b}}$, Per-Erik Mellander ${ }^{\mathrm{a}, \mathrm{b}}$, Karen Daly ${ }^{\mathrm{b}}$ \\ a Agricultural Catchments Programme, Teagasc, Johnstown Castle Environment Research Centre, Wexford, Ireland \\ b Crops, Environment and Land Use Programme, Teagasc, Johnstown Castle Environment Research Centre, Wexford, Ireland \\ c School of Geography and Environmental Sciences, Ulster University, Coleraine, UK
}

\section{H I G H L I G H T S}

- Medium-sized (200-450 nm) soil colloidal and soluble soil solution P were analysed.

- Amorphous forms of $\mathrm{Fe}$ increased the major fraction of medium-sized colloidal P.

- Soil $S_{\max }$ and DPS influenced mediumsized colloidal P and soluble P, respectively.

- Cattle slurry did not influence mediumsized colloidal P but increased soluble P.

- Synthetic fertilizer influenced mediumsized colloidal $P$ and increased soluble P.

\section{A R T I C L E I N F O}

\section{Article history:}

Received 16 April 2020

Received in revised form 24 August 2020

Accepted 29 August 2020

Available online 1 September 2020

Editor: Yucheng Feng

\section{Keywords:}

Soil water dispersible colloids

Mobilisation

Cattle slurry

Synthetic fertilizer

Agriculture

Groundwater pollution
G R A P H I C A L A B S T R A C T
P fertilizer

(organic, synthetic)

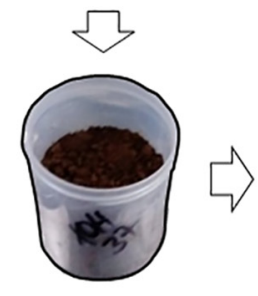

Incubation
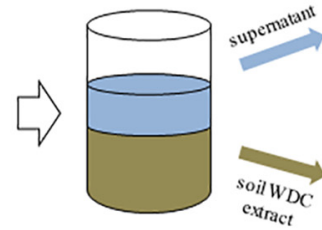

soil $_{W_{D C}}$
exa $_{\text {ract }}$
Soil solution soluble $\mathrm{P}$ (<450 nm)

Soil medium-sized colloidal P (200-450 nm)
Influencers:

Soil DPS

Org., synth. fertilizer

Soil M3-Fe, $\mathrm{S}_{\max }$

Synth. fertilizer

\section{A B S T R A C T}

Colloid-facilitated transport can be important for preferential transfer of phosphorus (P) through the soil profile to groundwater and may in part explain elevated $\mathrm{P}$ concentrations in surface water during baseflow and particularly high flow conditions. To investigate the potential for colloidal $\mathrm{P}\left(\mathrm{P}_{\text {coll }}\right)$ mobilisation in soils, this study assessed the role of soil chemical properties and P fertilizer type on medium-sized soil $\mathrm{P}_{\text {coll }}(200-450 \mathrm{~nm})$ and its association with soil solution soluble bioavailable P $(<450 \mathrm{~nm})$. Hillslope soils from three agricultural catchments were sampled and untreated and treated (cattle slurry and synthetic fertilizer) subsamples were incubated. Soil supernatants were analysed for P and soil Water Dispersible Colloids (WDC) were extracted for analysis of $\mathrm{P}$ and P-binding materials. Soils physicochemical properties including degree of P saturation (DPS) and P sorption properties were determined. Results indicated that medium-sized $\mathrm{P}_{\text {coll }}$ was mostly unreactive $\mathrm{P}$ associated to some extent to amorphous forms of Fe. Medium-sized $\mathrm{P}_{\text {coll }}$ concentrations correlated negatively with soil maximum P sorption capacity and soluble P concentrations increased with increasing DPS. In soil with low sorption properties, cattle slurry increased soluble P concentrations by $0.008-0.013 \mathrm{mg} \mathrm{l}^{-1}$ and DPS but did not influence medium-sized $\mathrm{P}_{\text {coll }}$. Synthetic fertilizer increased medium-sized reactive $\mathrm{P}_{\text {coll }}$ by $0.011 \mathrm{mg} \mathrm{l}^{-1}\left(0.088 \mathrm{mg} \mathrm{kg}^{-1}\right.$ soil) and DPS in a soil with lower DPS whereas it decreased it by $0.005 \mathrm{mg} \mathrm{l}^{-1}$ ( $0.040 \mathrm{mg} \mathrm{kg}^{-1}$ soil) in a soil with higher DPS. Additional soil parameters (M3-Fe, M3-Al, M3-P, and DPS) should be included in soil testing, especially in Cambisol/Podzol soils, to identify critical areas where risks of $\mathrm{P}_{\text {coll }}$ mobilisation are important. Further research should include the roles of finer colloidal and nanoparticulate $(<200 \mathrm{~nm})$ soil $\mathrm{P}$ fractions and soluble P to inform understanding of plant uptake and assess environmental risk. (c) 2020 Published by Elsevier B.V.

\footnotetext{
* Corresponding author.

E-mail address: maelle.fresne@hotmail.fr (M. Fresne).
} 


\section{Introduction}

Phosphorus (P) is a key nutrient for global food production (Némery and Garnier, 2016) but losses from agricultural soils into water bodies can lead to ecological issues caused by eutrophication (Andersen et al., 2017). A range of $P$ species can be found in water (Van Moorleghem et al., 2011) such as inorganic phosphate directly bioavailable in its dissolved form (Ekholm, 1994) or organic esters of phosphoric acid (Turner et al., 2005). Phosphate can also be present as colloidal phosphate precipitates, or associated with colloidal clay and metal oxide particles and become bioavailable after its release by dissolution or desorption, respectively (Jeanneau et al., 2014; Lambert et al., 2013), or by diffusion near the plant root (Montalvo et al., 2015). However, some studies suggest that some colloidal $\mathrm{P}\left(\mathrm{P}_{\text {coll }}\right)$ forms could be directly bioavailable (Van Moorleghem et al., 2013). Colloids present higher specific surface areas for P binding compared to bulk soil, are mobile in soil, remain in solution for long periods of time (Baalousha et al., 2005) and may thus be important for preferential transfer of nutrients and contaminants (Jiang et al., 2015; Missong et al., 2016) through the soil profile to groundwater (GW).

Colloidal P mobilisation in soils can depend on chemical drivers, including anoxia (Henderson et al., 2012), degree of P saturation (DPS) (Ilg et al., 2008; Siemens et al., 2004), pH (Séquaris et al., 2013) and ionic strength (Rousseau et al., 2004). Other reported dependencies include management-related drivers such as fertilizer rate of application (Zhang et al., 2003), fertilizer type (Heathwaite et al., 2005; Ilg et al., 2008) or ploughing of tillage soils (Schelde et al., 2006), and physical drivers such as rainfall rate (Rousseau et al., 2004), soil moisture (Jiang et al., 2013; Mohanty et al., 2015) and temperature (Jiang et al., 2017). Organic acids (contained in soils and animal slurry, for example) can also compete with phosphate for the same colloidal sorption sites via ligand exchange or solubilize phosphate via ligand promoted mineral dissolution (Oburger et al., 2011). This may alter the association between mobile soil $\mathrm{P}_{\text {coll }}$ and $\mathrm{P}$ that is dissolved and more easily bioavailable.

Groundwater pathway connectivity is important for P transfers and there is increasing evidence that GW P is a concern for stream water quality (Dupas et al., 2017; Mellander et al., 2016). While stream-bed and karst remobilisation of P (Hongthanat et al., 2016; Jarvie et al., 2014), P release from wetlands (Dupas et al., 2015), and rural point sources (Withers et al., 2014) may also contribute to river base flow $\mathrm{P}$ concentrations, the role of soil processes and pathways to GW are also of concern. For example, research has highlighted the large proportion of stream water P associated with nanoparticles and colloids and that were assumed to come from soil colloids (Gottselig et al., 2017). Thus, it is important to improve the understanding of the drivers of P transfer from agricultural soils to GW to be able to mitigate eutrophication and improve stream water quality.

Soil chemistry and nutrient management of agricultural soils are varied and the components and forms of P present in animal slurry are different from those in synthetic inorganic fertilizers. It was assumed that aluminium $(\mathrm{Al})$ and iron $(\mathrm{Fe})$ rich soils would increase soil $\mathrm{P}_{\text {coll }}$ whereas animal slurry would decrease soil $\mathrm{P}_{\text {coll. }}$. The aim of this study was to understand the role of soil $\mathrm{P}_{\text {coll }}$ in the soil-water system and how this relates to mobilisation potential in groundwater-fed agricultural catchments. The major objective was to determine the influence of organic and synthetic $\mathrm{P}$ fertilizer on medium-sized soil $\mathrm{P}_{\text {coll }}$ and soluble soil solution P fractions using incubated soil samples and laboratory extractions.

\section{Materials and methods}

\subsection{Sites description}

Soils from three long-term agricultural catchment observatories in Ireland (Fealy et al., 2010; Shortle and Jordan, 2017; Wall et al., 2012) were used for this study, specifically Grassland A, Grassland B and Arable $A$. These catchments were chosen because they had some evidence of groundwater-fed streams to a greater (Arable A and Grassland A) and lesser degree (Grassland B) (Dupas et al., 2017; Mellander et al., 2016; Mellander et al., 2015). The catchments also varied in terms of land use, soil drainage class, soil type and chemistry and geology (SI 1). All three catchments have intensively farmed land with a range of bioavailable $\mathrm{P}$ concentrations (Morgan soil $\mathrm{P}$ test) in soils ranging from sub-optimum to excessive (Wall et al., 2012). Grassland A and Arable A have hillslope transects with piezometer nests for GW monitoring where soils were sampled for this study. Grassland B has a series of discrete GW monitoring points and soils close to two of these were sampled (SI 2).

\subsection{Samples collection and pre-treatment}

Soil sampling was conducted in 4 fields in Grassland A (downslope Gleysol (GA-1, GA-3) and midslope Cambisol/Podzol (GA-2, GA-4) soils), 2 fields in Grassland B (Planosol/Stagnosol (GB-5) and Cambisol/Leptosol (GB-6) soils), and 4 fields in Arable A (downslope Luvisol (AA-7, AA-9) and midslope Cambisol (AA-8, AA-10) soils) (SI 2) between January and March 2018 before fertilizer applications. Soil was sampled using a hand auger from 0 to $40 \mathrm{~cm}$ (Dupas et al., 2015) at several points along two $\mathrm{W}$-shaped paths in an area of ca. $60 \mathrm{~m}^{2}$ adjacent to the piezometer nests to get one composite soil sample for each site. The topsoil and the horizon below were mixed to account for attenuation processes once $\mathrm{P}_{\text {coll }}$ has been mobilised in the topsoil, important when assessing $\mathrm{P}_{\text {coll }}$ mobilisation potential to $\mathrm{GW}$. In total, 10 composite soil samples were taken. All soil samples were air-dried (Dupas et al., 2015) and sieved to $12 \mathrm{~mm}$ to remove large stones and minimise soil aggregate destruction (De Boodt et al., 2013).

\subsection{Treatments and incubation study}

Before incubation, 5 treatments were applied on subsamples (triplicate, $150 \mathrm{~g}$ dry soil equivalent) of each of the 10 composite soil samples. The treatments included a control (C), a cattle slurry $\left(0.29 \mathrm{~kg} \mathrm{P} \mathrm{m}^{-3}\right)$ treatment of $1.99 \mathrm{mg} \mathrm{P} \mathrm{kg}^{-1}$ soil (CS1), a cattle slurry treatment of $3.99 \mathrm{mg} \mathrm{P} \mathrm{kg}^{-1}$ soil (CS2), a synthetic fertilizer treatment (10-10-20 $(\mathrm{N}-\mathrm{P}-\mathrm{K}))$ of $1.26 \mathrm{mg} \mathrm{P} \mathrm{kg}^{-1}$ soil (SF1) and a synthetic fertilizer treatment (10-10-20) of $2.53 \mathrm{mg} \mathrm{P} \mathrm{kg}^{-1}$ soil (SF2). The treatment types and application rates CS1 and SF1 were representative of the main farmers' practices in the catchments. Treatments CS2 and SF2 (double of CS1 and SF1) were used to assess the effect of application rate. The cattle slurry composition is shown in SI 3. In total, 150 soil subsamples were placed in $250 \mathrm{ml}$ pots and incubated in a growth room in darkness with a bulk density of $1.2 \mathrm{~g} \mathrm{~cm}^{-3}$ (O'Flynn et al., 2018) at $15{ }^{\circ} \mathrm{C}$ for 8 weeks (Sarker et al., 2014). A $10 \mathrm{~mm}$ hole was drilled in the lids to maintain aerobic conditions. Soil moisture was kept at $70 \%$ of waterfilled pore space (WFPS) by biweekly weighing each subsample and adding deionized water. Atmospheric humidity was kept between 70 and $80 \%$. A complete flow chart of the methodology showing treatments, tests and abbreviations is shown in SI 4.

\subsection{Chemical analysis}

After incubation, all subsamples were centrifuged at $4500 \mathrm{rcf}$ for 50 min to separate supernatants and soil cakes. Dilution factors ranging from 1.1 to 1.6 were applied to supernatants in order to provide enough soil solution for analysis. The supernatants were filtered using a $450 \mathrm{~nm}$ CA syringe filter (Sartorius) and analysed for dissolved reactive $\mathrm{P}$ $\left(D_{R P}\right)$ by spectrophotometry after ascorbic acid reduction (MDL: $0.005 \mathrm{mg} \mathrm{l}^{-1}$ ) (Askew and Smith, 2005). The soil cakes were then oven dried at $40{ }^{\circ} \mathrm{C}$ for 1 week and $2 \mathrm{~mm}$ sieved for further analysis (SI 4). A summary of abbreviations, descriptions and filtration sizes used for soil supernatants and colloidal extracts is presented in Table 1. 
Table 1

Summary of abbreviations, descriptions and filtration sizes used for soil supernatants and soil colloidal extracts.

\begin{tabular}{ll}
\hline Abbreviation & Description and filtration size \\
\hline Supernatant & $\begin{array}{l}\text { Soil solution separated from incubated soils by } \\
\text { centrifugation and filtered at } \mathbf{4 5 0} \mathbf{~ n m}\end{array}$ \\
$\mathrm{DRP}_{\mathrm{ss}}$ & $\begin{array}{l}\text { Soil solution dissolved reactive phosphorus } \\
\text { Medium-sized soil colloids extracted with water from } \\
\text { Water dispersible }\end{array}$ \\
soil colloids & $\begin{array}{l}\text { incubated soils and separated by membrane filtration } \\
(\mathbf{2 0 0}-\mathbf{4 5 0} \mathbf{~ n m})\end{array}$ \\
$\mathrm{TP}_{\text {coll }}$ & Total colloidal phosphorus \\
$\mathrm{RP}_{\text {coll }}$ & Reactive colloidal phosphorus \\
$\mathrm{UP}_{\text {coll }}$ & Unreactive colloidal phosphorus, difference between total \\
$\mathrm{Al}_{\text {coll }}, \mathrm{Fe}_{\text {coll }}, \mathrm{Si}_{\text {coll }}$ & and reactive colloidal phosphorus \\
$\mathrm{OC}_{\text {coll }}$ & Colloidal aluminium, colloidal iron, colloidal silicate \\
\hline
\end{tabular}

\subsubsection{Un-incubated bulk soil variability}

The 10 un-incubated composite soil samples were characterised according to potential $\mathrm{P}_{\text {coll }}$ influences. For clay content, particle size distribution (PSD - sand, silt and clay content (\%) (Brady and Weil, 2008)) were determined using the pipette method (Avery and Bascomb, 1974) and converted to textural classes (SI 4).

\subsubsection{Incubated bulk soil variability}

For the 150 incubated centrifuged soil cakes, the major soil $\mathrm{P}$ chemical precipitation/adsorption factors $\mathrm{Al}$, Fe and calcium (Ca) were determined by Mehlich 3 extraction (Mehlich, 1984) in a 1:10 soil-toMehlich 3 reagent ratio for labile inorganic fractions determination. Mehlich 3 extractable P (M3-P), Al (M3-Al), Fe (M3-Fe) and Ca (M3Ca) were measured by Varian VISTA Inductively coupled plasmaoptical emission spectroscopy (ICP-OES - Varian, Palo Alto, CA). Total phosphorus (TP), aluminium (TAl), iron (TFe) and calcium (TCa) were similarly measured by ICP-OES after Nitric Acid $(7.5 \mathrm{ml})$ and Hydrochloric Acid $(2.5 \mathrm{ml})$ microwave digestion on $0.5 \mathrm{~g}$ soil samples (EPA 3052, 1996). Soil DPS (\%) was calculated using the sum of M3-Al and M3-Fe as the denominator and M3-P as the numerator (Kovar and Pierzynski, 2009). Phosphorus sorption isotherms were also established in duplicate on the control (C) subsamples (using a composite sample of the triplicates) to note soil binding and $\mathrm{P}$ buffering characteristics following the technique of Pautler and Sims (2000). Two grams of soil were shaken $(15 \mathrm{rpm})$ for $24 \mathrm{~h}$ with $30 \mathrm{ml}$ of $6 \mathrm{P}$ solutions ranging from 0 to $25 \mathrm{mg} \mathrm{P} \mathrm{l}^{-1}$ (as $\mathrm{KH}_{2} \mathrm{PO}_{4}$ ). The suspensions were then filtered (Whatman filter paper no. 2) and analysed colorimetrically for reactive $\mathrm{P}(\mathrm{RP})$. The difference between $\mathrm{P}$ added in the initial solutions and $\mathrm{P}$ remaining in the filtrates was considered to have been sorbed. Maximum $\mathrm{P}$ sorption capacity $\left(\mathrm{S}_{\max }\right)$ and $\mathrm{P}$ binding energy $(\mathrm{k})$ were calculated using the Langmuir adsorption equation (Kovar and Pierzynski, 2009).

Soil pH was determined using a 1:2.5 soil-to-water ratio (Bryne, 1979). Organic matter content (OM\%) was measured as the loss-onignition of $4 \mathrm{~g}$ samples at $500{ }^{\circ} \mathrm{C}$ (Storer, 1984). Blank and control samples were used in the extractions and P determination procedures to ensure analysis reliability (SI 4).

\subsubsection{Incubated medium-sized soil colloids extraction and analysis}

To examine the medium-sized colloidal fractions in each incubated soil cakes, Water Dispersible Colloids (WDCs) were extracted as they are easily dispersed from soil in contact with water (Rieckh et al., 2015) and have been suggested as model compounds for mobile soil colloids (Séquaris et al., 2013). Soil (20 g) was shaken (reciprocal shaker) with deionized water (1:8 soil-to-water ratio) for $24 \mathrm{~h}$. The supernatant was then centrifuged at $3000 \mathrm{rcf}$ for $10 \mathrm{~min}$ and filtered using a $450 \mathrm{~nm}$ CA membrane filter (Whatman) and a vacuum system. This is a modified procedure compared to Ilg et al. (2005) and Liu et al. (2014) to account for the dissolved $\mathrm{P}$ fraction, similar to the procedure for determining P in GW in the studied catchments and by consequence does not consider the larger colloidal fraction ( $>450 \mathrm{~nm}$ ). Approximately half of the filtrate was then re-filtered using a $200 \mathrm{~nm}$ membrane filter and both filtrates were subsequently analysed for $\mathrm{P}_{\text {coll }}$ fractions and factors influencing $\mathrm{P}_{\text {coll }}$ binding ( $\mathrm{Fe}$ and $\mathrm{Al}$ hydroxides, aluminosilicates, and OM). Total dissolved P (TDP) after alkaline persulphate oxidation (Askew, 2005) and, with DRP, after ascorbic acid reduction (MDL: $0.005 \mathrm{mg} \mathrm{l}^{-1}$ ) (Askew and Smith, 2005) were analysed by spectrophotometry. Aluminium, Fe and silicate $(\mathrm{Si})$ were analysed on a Varian Vista-MPX CCD-Simultaneous ICP-OES (IDL: $1 \mu \mathrm{g} \mathrm{l}^{-1}$ ) (Gottler and Piwoni, 2005), dissolved organic carbon (OC) was analysed by a nonDiffractive Infra-Red (NDIR) detector after acidification and combustion (Baird, 2005). Medium-sized soil total $\mathrm{P}_{\text {coll }}\left(\mathrm{TP}_{\text {coll }}\right)$, reactive $\mathrm{P}_{\text {coll }}\left(\mathrm{RP}_{\text {coll }}\right)$, unreactive $\mathrm{P}_{\text {coll }}\left(\mathrm{UP}_{\text {coll }}\right)$, and colloidal $\mathrm{OC}\left(\mathrm{OC}_{\text {coll }}\right), \mathrm{Fe}\left(\mathrm{Fe}_{\text {coll }}\right), \mathrm{Al}\left(\mathrm{Al}_{\text {coll }}\right)$ and $\mathrm{Si}\left(\mathrm{Si}_{\text {coll }}\right)$ were measured as the difference between their concentrations in the $200 \mathrm{~nm}$ unfiltered sample $(<450 \mathrm{~nm}$ fraction) and the $200 \mathrm{~nm}$ filtered sample ( $<200 \mathrm{~nm}$ fraction) (SI 4, Table 1 ). Blank samples were used to ensure analysis reliability.

\subsection{Statistical and data analysis}

Pearson's correlation analysis was conducted to examine the relationship between medium-sized colloidal fractions, especially $\mathrm{P}_{\text {coll }}$, and all PSD and chemical results from the un-incubated composite soil samples and the control (C) incubated soil cake samples, respectively, including the centrifuged supernatants $\mathrm{DRP}_{\mathrm{ss}}$. Significant correlation coefficients were determined at $\mathrm{P}<0.05$. A closer analysis was undertaken on the WDC fractions to test for significant correlations between these fractions.

To test for the significant effect $(\mathrm{P}<0.05)$ of fertilizer application on soil M3-P, medium-sized soil $\mathrm{P}_{\text {coll }}$, DPS and centrifuged supernatant $\mathrm{DRP}_{\mathrm{sS}}$ fractions within and between each soil, ANOVA was conducted on chemical results from the control (C) and treated (CS1, CS2, SF1, SF2) incubated soil cakes samples and the centrifuged supernatants $\mathrm{DRP}_{\text {ss. }}$ Cattle slurry $(\mathrm{CS} 1, \mathrm{CS} 2)$ and synthetic fertilizer (SF1, SF2) treatments were analysed separately as the application rates were different. Residuals plots were used to assess the normal distribution of the residuals and the equal variance of the data; data were log transformed before statistical analyses when those conditions were not met. To test for changes in the strength of factors influencing medium-sized soil $\mathrm{P}_{\text {coll }}$ and $\mathrm{DRP}_{\mathrm{ss}}$, Pearson's correlation analysis was conducted to examine the relationship between medium-sized colloidal fractions, especially $\mathrm{P}_{\text {coll }}$, and all PSD and chemical results from the un-incubated composite soil samples and the treated (CS1, CS2, SF1, SF2) incubated soil cake samples, respectively, including the centrifuged supernatants $\mathrm{DRP}_{\mathrm{ss}}$.

All statistical analysis was carried out using R Studio version 3.5.2. Negative values in the WDC fractions due to a very small difference in concentrations between the two filtrates and/or concentrations below the detection limit or measurement error were counted as zero concentrations.

\section{Results}

\subsection{Soils characteristics}

\subsubsection{Bulk soils}

A summary of bulk soils characteristics is shown in Table 2. A correlation matrix between soil properties, $\mathrm{P}$ sorption parameters, $\mathrm{DRP}_{\mathrm{ss}}$ and medium-sized colloidal fractions in untreated soils is also shown in Table 3. The Gleysol soils (GA-1, GA-3) showed the highest sand content (62\%) whereas the Planosol/Stagnosol (GB-5) and Luvisol soils (AA-7, AA-9) showed the highest clay contents (26-28\%). Concentrations of medium-sized $\mathrm{RP}_{\text {coll }}$ were positively correlated to clay content and, as expected, negatively correlated to sand content. Soil OM content ranged from 4.6\% (Gleysol GA-3) to 8.3\% (Cambisol/Podzol GA-4) and the range was too narrow to see any significant effect on medium-sized $\mathrm{P}_{\text {coll }}$. 
Table 2

Summary of untreated soils characteristics.

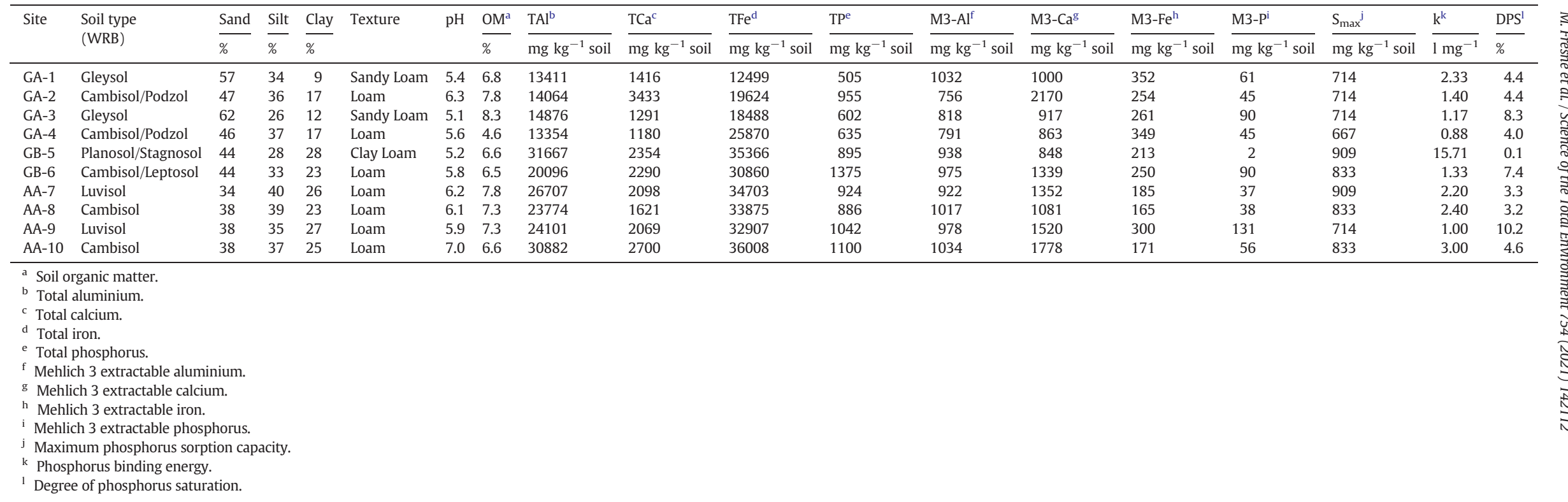


Table 3

Pearson correlation matrix between soil properties, sorption parameters, soil solution dissolved reactive phosphorus and medium-sized soil colloidal fractions in untreated soils ( $\mathrm{n}=30$ ). Significant correlations are shown in bold.

\begin{tabular}{|c|c|c|c|c|c|c|c|c|c|c|c|c|c|c|c|c|c|c|c|c|c|c|c|}
\hline & Sand & Silt & Clay & $\mathrm{pH}$ & $\mathrm{OM}^{\mathrm{a}}$ & $S_{\max }^{b}$ & $\mathrm{k}^{\mathrm{c}}$ & $\mathrm{DPS}^{\mathrm{d}}$ & $\mathrm{TAl}^{\mathrm{e}}$ & $\mathrm{TCa}^{\mathrm{f}}$ & $\mathrm{TFe}^{\mathrm{g}}$ & $\mathrm{TP}^{\mathrm{h}}$ & M3-Al ${ }^{\mathrm{i}}$ & M3-Ca ${ }^{\mathrm{j}}$ & M3-Fe ${ }^{\mathrm{k}}$ & M3-P $\mathrm{P}^{\mathrm{l}}$ & $\mathrm{DRP}_{\mathrm{ss}}{ }^{\mathrm{m}}$ & $\mathrm{TP}_{\text {coll }}{ }^{\mathrm{n}}$ & $\mathrm{UP}_{\text {coll }^{\circ}}$ & $\mathrm{RP}_{\text {coll }}{ }^{\mathrm{P}}$ & $\mathrm{Al}_{\text {coll }^{9}}{ }^{\mathrm{q}}$ & $\mathrm{Fe}_{\text {coll }}{ }^{\mathrm{r}}$ & $\mathrm{Si}_{\text {coll }}{ }^{\mathrm{s}}$ \\
\hline \multicolumn{24}{|l|}{ Sand } \\
\hline Silt & -0.70 & & & & & & & & & & & & & & & & & & & & & & \\
\hline Clay & -0.86 & 0.24 & & & & & & & & & & & & & & & & & & & & & \\
\hline $\mathrm{pH}$ & -0.66 & 0.73 & 0.37 & & & & & & & & & & & & & & & & & & & & \\
\hline $\mathrm{OM}$ & 0.11 & -0.19 & -0.01 & 0.06 & & & & & & & & & & & & & & & & & & & \\
\hline $\mathrm{S}_{\max }$ & -0.56 & 0.08 & 0.71 & 0.24 & 0.16 & & & & & & & & & & & & & & & & & & \\
\hline $\mathrm{k}$ & -0.07 & -0.46 & 0.42 & -0.32 & -0.11 & 0.57 & & & & & & & & & & & & & & & & & \\
\hline DPS & 0.19 & -0.12 & -0.17 & -0.02 & 0.28 & -0.51 & -0.66 & & & & & & & & & & & & & & & & \\
\hline TAl & -0.65 & 0.08 & 0.83 & 0.36 & 0.09 & 0.78 & 0.55 & -0.31 & & & & & & & & & & & & & & & \\
\hline $\mathrm{TCa}$ & -0.35 & 0.16 & 0.37 & 0.51 & 0.24 & 0.27 & 0.16 & -0.12 & 0.29 & & & & & & & & & & & & & & \\
\hline TFe & -0.86 & 0.31 & 0.95 & 0.44 & -0.13 & 0.71 & 0.34 & -0.20 & 0.84 & 0.22 & & & & & & & & & & & & & \\
\hline TP & -0.55 & 0.21 & 0.60 & 0.46 & 0.04 & 0.41 & 0.01 & 0.17 & 0.42 & 0.72 & 0.56 & & & & & & & & & & & & \\
\hline M3-Al & -0.33 & 0.19 & 0.32 & 0.25 & 0.00 & 0.45 & 0.14 & -0.02 & 0.53 & -0.09 & 0.38 & 0.22 & & & & & & & & & & & \\
\hline M3-Ca & -0.37 & 0.43 & 0.19 & 0.75 & 0.33 & -0.04 & -0.32 & 0.21 & 0.07 & 0.76 & 0.08 & 0.46 & -0.10 & & & & & & & & & & \\
\hline M3-Fe & 0.57 & -0.20 & -0.63 & -0.53 & -0.39 & -0.80 & -0.28 & 0.33 & -0.69 & -0.38 & -0.68 & -0.43 & -0.27 & -0.26 & & & & & & & & & \\
\hline M3-P & 0.14 & -0.09 & -0.13 & -0.02 & 0.21 & -0.49 & -0.62 & 0.99 & -0.26 & -0.14 & -0.16 & 0.18 & 0.11 & 0.18 & 0.37 & & & & & & & & \\
\hline $\mathrm{DRP}_{\mathrm{ss}}$ & -0.20 & -0.01 & 0.27 & 0.00 & 0.17 & -0.27 & -0.30 & 0.79 & 0.06 & -0.03 & 0.18 & 0.26 & 0.16 & 0.18 & 0.23 & 0.83 & & & & & & & \\
\hline $\mathrm{TP}_{\text {coll }}$ & -0.09 & 0.21 & -0.03 & -0.01 & -0.52 & -0.43 & -0.27 & 0.25 & -0.21 & -0.25 & 0.03 & -0.07 & -0.11 & -0.11 & 0.46 & 0.28 & 0.37 & & & & & & \\
\hline $\mathrm{UP}_{\text {coll }}$ & -0.04 & 0.18 & -0.08 & -0.04 & -0.53 & -0.46 & -0.24 & 0.20 & -0.25 & -0.27 & -0.02 & -0.13 & -0.17 & -0.13 & 0.48 & 0.22 & 0.32 & 0.99 & & & & & \\
\hline $\mathrm{RP}_{\text {coll }}$ & -0.45 & 0.30 & 0.39 & 0.21 & -0.07 & 0.14 & -0.28 & 0.41 & 0.21 & 0.01 & 0.39 & 0.50 & 0.42 & 0.12 & -0.06 & 0.47 & 0.46 & 0.25 & 0.13 & & & & \\
\hline $\mathrm{Al}_{\text {coll }}$ & -0.42 & 0.43 & 0.26 & 0.36 & -0.19 & 0.11 & -0.23 & 0.07 & 0.20 & 0.07 & 0.33 & 0.27 & 0.15 & 0.16 & -0.16 & 0.09 & 0.16 & 0.32 & 0.30 & 0.35 & & & \\
\hline $\mathrm{Fe}_{\text {coll }}$ & -0.47 & 0.47 & 0.30 & 0.41 & -0.10 & 0.19 & -0.22 & 0.03 & 0.25 & 0.08 & 0.37 & 0.25 & 0.20 & 0.17 & -0.25 & 0.05 & 0.13 & 0.27 & 0.25 & 0.34 & 0.96 & & \\
\hline $\mathrm{Si}_{\text {coll }}$ & -0.42 & 0.39 & 0.29 & 0.29 & -0.18 & 0.10 & -0.20 & 0.10 & 0.21 & 0.02 & 0.33 & 0.22 & 0.15 & 0.12 & -0.11 & 0.13 & 0.23 & 0.31 & 0.29 & 0.35 & 0.98 & 0.93 & \\
\hline
\end{tabular}

a Soil organic matter.

b Maximum phosphorus sorption capacity.

c Phosphorus binding energy.

degree of phosphorus saturation.

Total aluminium.

${ }^{\mathrm{f}}$ Total calcium.

g Total iron.

Total phosphorus.

Mehlich 3 extractable aluminium.

${ }^{5}$ Mehlich 3 extractable calcium.

kehlich 3 extractable iron.

Mehlich 3 extractable phosphorus.

m Soil solution dissolved reactive phosphorus.

n Total colloidal phosphorus.

o Unreactive colloidal phosphorus.

p Reactive colloidal phosphorus.

${ }^{q}$ Colloidal aluminium.

r Colloidal iron.
s Colloidal silicate. 
Soil TP content was the highest in the Cambisol/Leptosol soil (GB6; $1375 \mathrm{mg} \mathrm{kg}^{-1}$ soil) and the lowest in Gleysol soils (GA-1, GA-3; 505-602 $\mathrm{mg} \mathrm{kg}^{-1}$ soil). The highest TAl and TFe contents were measured in Planosol/Stagnosol (GB-5) and Cambisol (AA-10) soils whereas the lowest contents were measured in Gleysol (GA-1, GA3) and Cambisol/Podzol (GA-2, GA-4) soils. Soil M3-P content was the highest in a Luvisol soil (AA-9; $131 \mathrm{mg} \mathrm{kg}^{-1}$ soil) and the lowest in the Planosol/Stagnosol soil (GB-5; $2 \mathrm{mg} \mathrm{kg}^{-1}$ soil). The highest $\mathrm{M} 3-\mathrm{Al}$ and M3-Fe contents were measured in Cambisol (AA-10) and Gleysol (GA-1) soils, respectively. The lowest M3-Al and M3-Fe contents were measured in Cambisol/Podzol (GA-2, GA-4) and Cambisol (AA-8, AA-10) soils, respectively. Soil M3-P was positively correlated to $\mathrm{DRP}_{\mathrm{sS}}(\mathrm{R}=0.83)$. Soil M3-Al and M3-Fe contents were positively correlated to medium-sized $\mathrm{RP}_{\text {coll }}$ and $\mathrm{UP}_{\text {coll }}$ concentrations, respectively, as assumed.

Soil DPS was the highest in a Luvisol soil (AA-9; 10.2\%) and the lowest in the Planosol/Stagnosol soil (GB-5; 0.1\%). Soil DPS was positively correlated to $\mathrm{DRP}_{\mathrm{ss}}(\mathrm{R}=0.79)$ and negatively correlated to $\mathrm{k}(\mathrm{R}=$ $-0.66)$.

Soil P sorption isotherms are shown in Fig. 1 and $S_{\max }$ and $\mathrm{k}$ values in Table 2. Maximum $P$ sorption capacity $S_{\max }$ was the highest for Planosol/Stagnosol (GB-5) and Luvisol (AA-7) soils (909 mg P kg-1 soil) and the lowest for a Cambisol/Podzol soil (GA-4; $667 \mathrm{mg} \mathrm{P} \mathrm{kg}{ }^{-1}$ soil). Soil P binding energy $k$ was the lowest for Cambisol/Podzol (GA4) and Luvisol (AA-9) soils (0.88-1.00 $\mathrm{l} \mathrm{mg}^{-1}$ ) and the highest for the Planosol/Stagnosol soil (GB-5; $3.00 \mathrm{l} \mathrm{mg}^{-1}$ ). Soil $\mathrm{S}_{\max }$ was negatively correlated to medium-sized $\mathrm{TP}_{\text {coll }}$ and $\mathrm{UP}_{\text {coll. }}$ Soil $\mathrm{k}$ and especially $\mathrm{S}_{\max }$ were positively correlated to clay content and TAl content. Soil $S_{\max }$ and $\mathrm{k}$ were also negatively correlated to M3-Fe and M3-P, respectively.

\subsubsection{Medium-sized soil colloids and soil solution}

Medium-sized $\mathrm{P}_{\text {coll }}$ and colloidal metal ( $\mathrm{Al}, \mathrm{Fe}, \mathrm{Si}$ ) concentrations across the 10 sites are shown in Fig. 2 and correlations between medium-sized colloidal fractions are shown in Table 3. Concentrations of $\mathrm{OC}_{\text {coll }}$ are not shown as results were all negative and assumed to be due to too small a difference in concentrations leading to measurements below the detection limit or measurement error. This may indicate that $\mathrm{P}_{\text {coll }}$ was not associated with $\mathrm{OM}$ in the medium-sized colloidal fraction. Concentrations of medium-sized $\mathrm{TP}_{\text {coll }}, \mathrm{UP}_{\text {coll }}$ and $\mathrm{RP}_{\text {coll }}$ ranged from 0.000 to $0.046 \mathrm{mg} \mathrm{l}^{-1}$, from 0.000 to $0.045 \mathrm{mg} \mathrm{l}^{-1}$ and from 0.000 to $0.007 \mathrm{mg} \mathrm{l}^{-1}$, respectively. The highest medium-sized $\mathrm{TP}_{\text {coll }}$ and $\mathrm{UP}_{\text {coll }}$ concentrations were measured in Cambisol/Podzol (GA-4) and to a less extent in Luvisol (AA-9) soils where $\mathrm{UP}_{\text {coll }}$ concentrations were variable. The lowest medium-sized $\mathrm{TP}_{\text {coll }}$ and $\mathrm{UP}_{\text {coll }}$ concentrations were measured in the Planosol/Stagnosol soil (GB-5). Concentrations of medium-sized $\mathrm{TP}_{\text {coll }}$ and $\mathrm{UP}_{\text {coll }}$ were very strongly correlated $(\mathrm{R}=$
0.99). The highest values of medium-sized $\mathrm{Al}_{\text {coll }}, \mathrm{Fe}_{\text {coll }}$ and $\mathrm{Si}_{\text {coll }}$ concentrations were recorded in Luvisol (AA-7, AA-9), Cambisol (AA-8, AA-10) and Cambisol/Leptosol (GB-6) soils but also in a Cambisol/Podzol (GA-4) soil. However, concentrations were variable for all these sites. Concentrations of medium-sized $\mathrm{Al}_{\text {coll }}$ and $\mathrm{Fe}_{\text {coll }}$ were very strongly correlated with each other $(\mathrm{R}=0.96)$, as were medium-sized $\mathrm{Al}_{\text {coll }}$ and $\mathrm{Si}_{\text {coll }}$ concentrations $(\mathrm{R}=0.98)$ and medium-sized $\mathrm{Fe}_{\text {coll }}$ and $\mathrm{Si}_{\text {coll }}$ concentrations $(R=0.93)$. Only medium-sized $R_{\text {coll }}$ concentrations were positively but moderately correlated to medium-sized $\mathrm{Al}_{\text {coll }}, \mathrm{Fe}_{\text {coll }}$ and $\mathrm{Si}_{\text {coll }}$ concentrations.

Concentrations of $\mathrm{DRP}_{\text {ss }}$ are also shown in Fig. 2 and ranged from 0.006 to $0.134 \mathrm{mg} \mathrm{l}^{-1}$. The highest and lowest concentrations were measured in a Luvisol soil (AA-9) and in the Planosol/Stagnosol soil (GB-5), respectively.

\subsection{Treated soils phosphorus fractions}

\subsubsection{Bulk soil phosphorus}

For the cattle slurry treatment, ANOVA showed an increase in the labile inorganic P pool (i.e. M3-P) in soil AA-8 after CS1, in soils GA-1, GA2 and GA-3 after CS2 and in soil GA-4 after CS1 and CS2 treatments (with no difference between CS1 and CS2). The synthetic fertilizer treatment had no effect on soil M3-P. In treated soils ( $n=120)$, M3-P and DPS were strongly correlated to $\mathrm{DRP}_{\mathrm{sS}}(\mathrm{R}=0.83$ and 0.80 , respectively).

\subsubsection{Medium-sized soil colloids and soil solution phosphorus}

Concentrations of medium-sized UP coll were not influenced by any of the P treatments (Fig. 3). However, medium-sized $\mathrm{RP}_{\text {coll }}$ concentrations decreased by $0.005 \mathrm{mg} \mathrm{Pl}^{-1}$ in Luvisol soil AA-9 (with no variation in soil DPS) and increased by $0.011 \mathrm{mg} \mathrm{P}^{-1}$ in Cambisol/Podzol soil GA4 after SF2 (synthetic fertilizer $2.53 \mathrm{mg} \mathrm{P} \mathrm{kg}^{-1}$ soil, $12.1 \mathrm{~kg} \mathrm{P} \mathrm{ha}^{-1}$ ) treatment (also compared to SF1) (Fig. 3) as was soil DPS. Increase in medium-sized $\mathrm{TP}_{\text {coll }}$ concentrations $\left(0.005 \mathrm{mg} \mathrm{P}^{-1}\right)$ between SF1 and SF2 treatments in Gleysol soil GA-1 was not associated with variation in soil DPS. A DRP $\mathrm{ss}$ increase of $0.021 \mathrm{mg} \mathrm{P}^{-1}$ was also measured in Cambisol/Leptosol soil GB-6 after SF2 treatment with no change in soil DPS. Application of SF1 (synthetic fertilizer $1.26 \mathrm{mg} \mathrm{P} \mathrm{kg}^{-1}$ soil), CS1 and CS2 (cattle slurry 1.99 and $3.99 \mathrm{mg} \mathrm{P} \mathrm{kg}^{-1}$ soil, respectively) treatments did not affect medium-sized $\mathrm{P}_{\text {coll }}$ concentrations even though DPS increased in some soils after CS1 (GA-4) and CS2 (GA-1, GA-3, GA-4, GB-6) treatments. However, $\mathrm{DRP}_{\text {ss }}$ increased after CS1 and CS2 treatments ( 0.008 and $0.013 \mathrm{mg} \mathrm{P}^{-1}$, respectively) in Cambisol/Podzol soil GA-4 as was soil DPS. Even at a higher application rate than the synthetic fertilizer treatment (SF2), the cattle slurry treatment (CS2) did not influence medium-sized $P_{\text {coll }}$ concentrations. However, concentrations were variable in GA-4, AA-9 and to a lesser extent GB-6 soils.
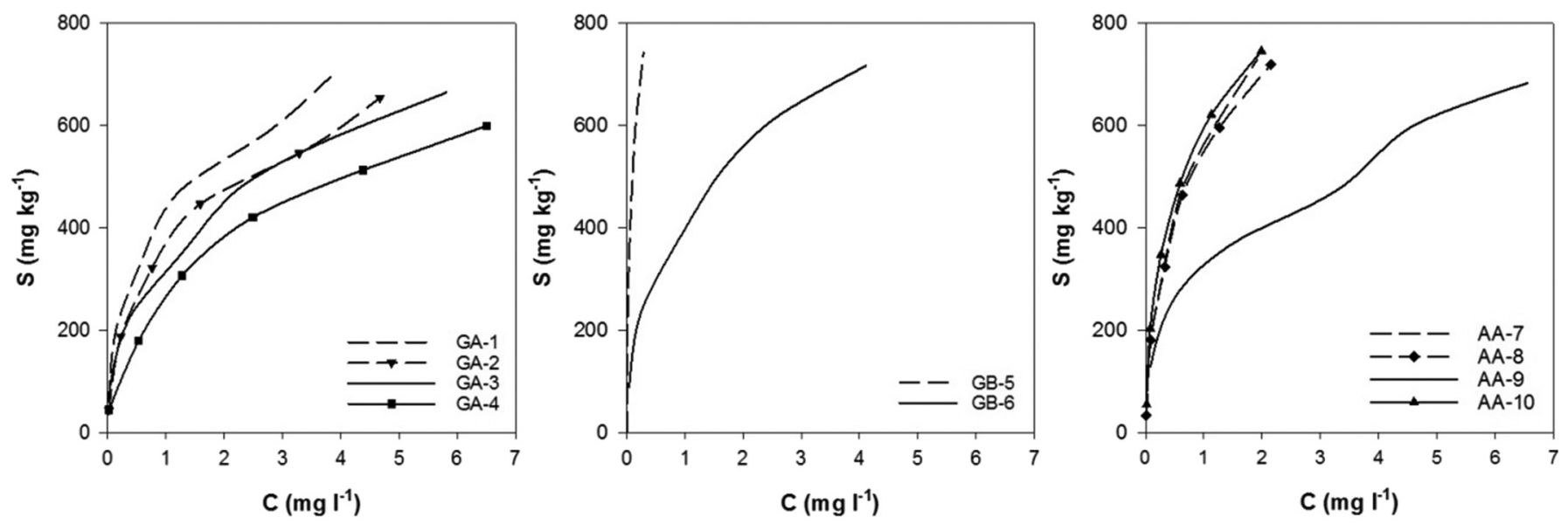

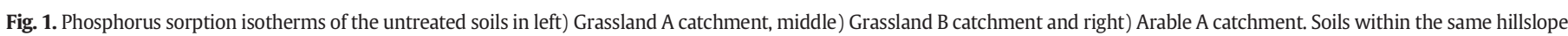
are presented with the same line style (solid or dash), soils at midslope are presented with symbols. All measurements were conducted in duplicate. 


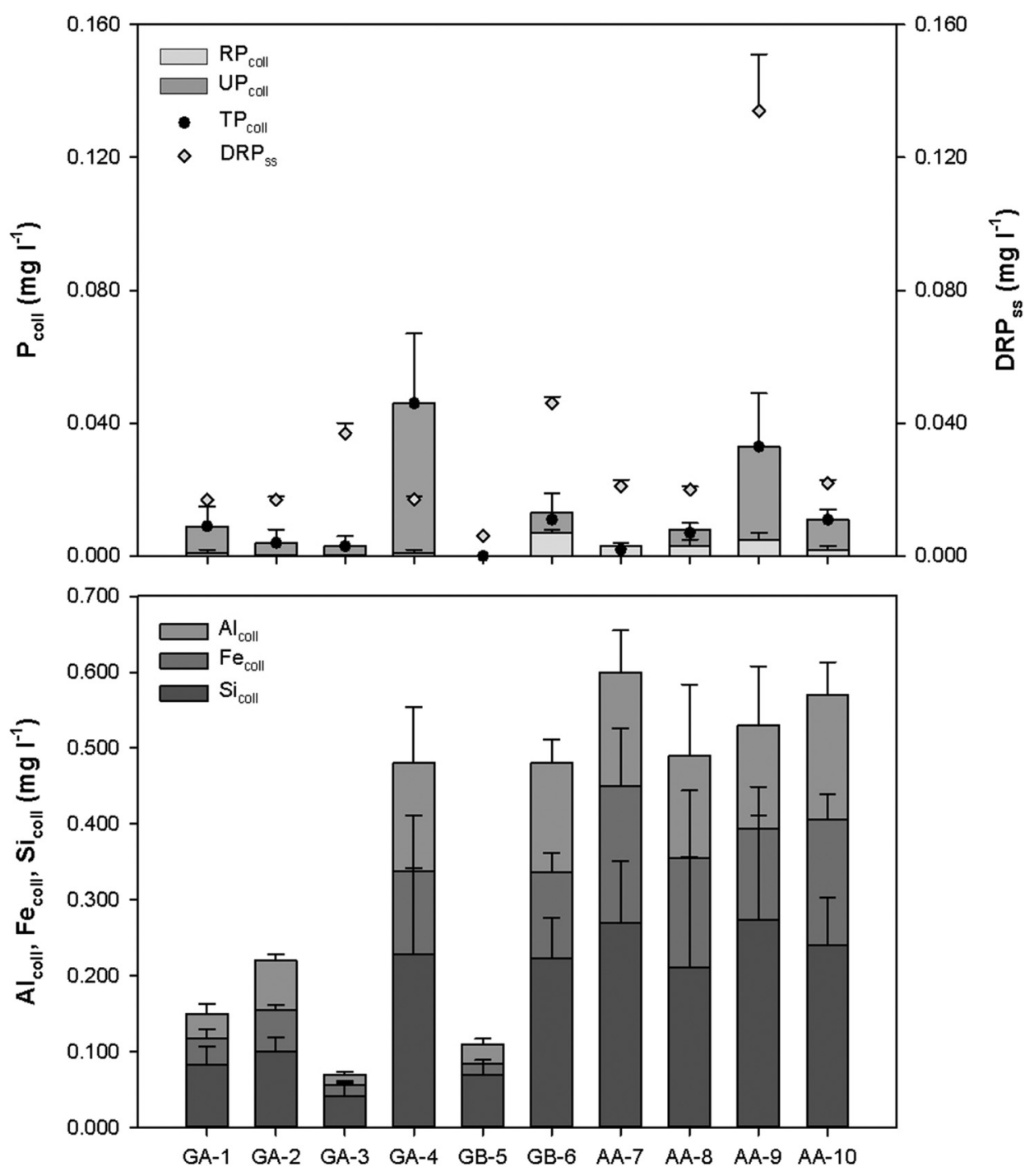

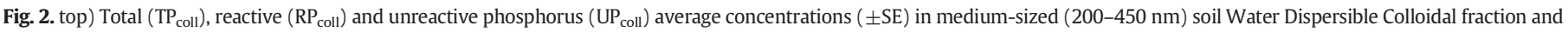

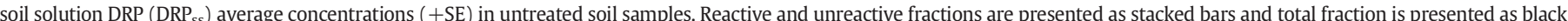

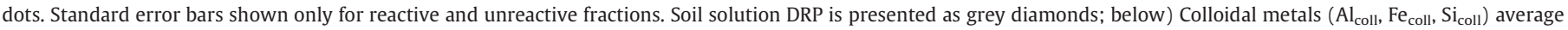
concentrations $( \pm \mathrm{SE})$ in medium-sized $(200-450 \mathrm{~nm})$ soil Water Dispersible Colloidal fraction in untreated soil samples. All measurements were conducted in triplicate.

After $\mathrm{P}$ application, medium-sized $\mathrm{TP}_{\text {coll }}$ and $\mathrm{UP}_{\text {coll }}$ remained strongly correlated with each other $(R=0.98)$ as were medium-sized colloidal metals ( $\mathrm{Al}, \mathrm{Fe}, \mathrm{Si})(\mathrm{R}=0.99)$.

\section{Discussion}

This study assessed the role of soil physical and chemical properties and $\mathrm{P}$ fertilization practices on soluble $\mathrm{P}$ and medium-sized $\mathrm{P}_{\text {coll }}$ concentrations in contrasting agricultural soils and the implications for leaching of $\mathrm{P}_{\text {coll }}$ to GW.

\subsection{Influence of soil properties on medium-sized colloidal phosphorus}

Colloidal P concentrations differed between untreated soils and medium-sized $\mathrm{P}_{\text {coll }}$ was mostly composed of unreactive $\mathrm{P}$ associated to amorphous forms of Fe. Previous studies also demonstrated that especially organic P (part of the unreactive fraction) was associated with WDCs (Jiang et al., 2015; Missong et al., 2016). As initially assumed, soil $\mathrm{M} 3-\mathrm{Fe}$ and $\mathrm{M} 3-\mathrm{Al}$ increased unreactive and reactive medium-sized $\mathrm{P}_{\text {coll }}$, respectively. The strong correlation found between medium-sized colloidal metals ( $\mathrm{Al}$, Fe and $\mathrm{Si}$ ) suggested the presence of clay minerals such as phyllosilicate, as found by Missong et al., (2018a) in the medium-sized colloidal fraction, and sesquioxides of $\mathrm{Fe}$ and $\mathrm{Al}$.

Soil M3-Fe, DPS and sorption parameters ( $S_{\max }$ and $\mathrm{k}$ ) appeared to be the main controlling factors of medium-sized $\mathrm{P}_{\text {coll }}$ mobilisation and soluble P concentrations. Higher medium-sized $\mathrm{TP}_{\text {coll }}$ and $\mathrm{UP}_{\text {coll }}$ concentrations were associated with higher soil M3-Fe content and lower soil $\mathrm{S}_{\max }$ and $\mathrm{k}$ whereas lower medium-sized $\mathrm{TP}_{\text {coll }}$ and $\mathrm{UP}_{\text {coll }}$ concentrations were associated with higher $S_{\text {max }}$, $k$ and lower DPS. Higher soluble $P$ concentrations, that include in part medium-sized $\mathrm{P}_{\text {coll }}$, were also associated with higher soil DPS. Evidence of the effect of high $P$ saturation on the dispersion of colloid-bound $P$ due to more mobilisation and higher $P$ content (Ilg et al., 2005) has been previously supported by Siemens et al. (2004) and Ilg et al. (2008). High soil $\mathrm{S}_{\max }$ also appeared to decrease medium-sized $\mathrm{P}_{\text {coll }}$ mobilisation and was here positively correlated to soil TAl and clay contents. Higher mobilisation of medium-sized $\mathrm{P}_{\text {coll }}$ in the Cambisol/Podzol soil (GA-4) could be related to the high mobility of OM-Fe associations and supports previous findings of Missong et al. (2018b) on the dominance of OM in leached colloids. Moreover, low medium-sized $\mathrm{P}_{\text {coll }}$ concentrations measured in the soil with the highest OM content (GA-3) could possibly indicate that $\mathrm{P}_{\text {coll }}$ may mainly be in the fine colloidal and nanoparticulate fractions ( $<200 \mathrm{~nm}$ ) (not studied here), richer in OM as suggested by Missong et al. (2018a). Results may 


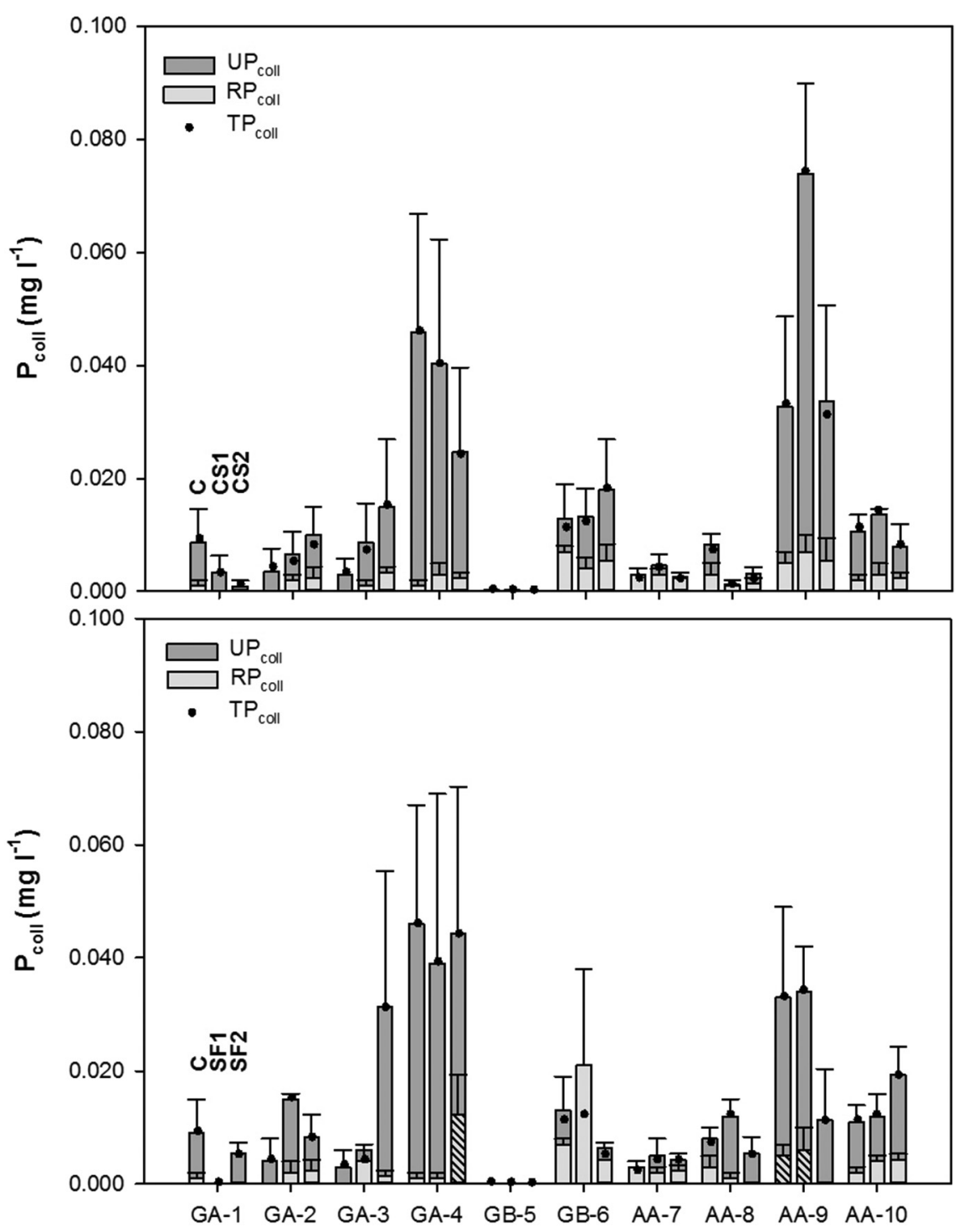

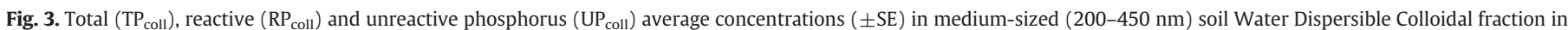

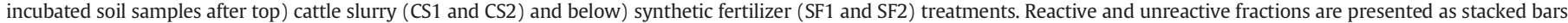

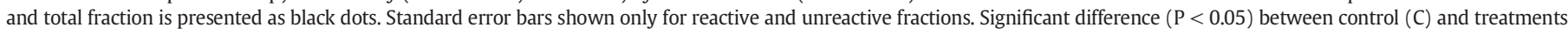
(CS1 or CS2, SF1 or SF2) or between treatment application rates within each site are shown with diagonals. All measurements were conducted in triplicate.

indicate that background soil OM content attenuate medium-sized $\mathrm{P}_{\text {coll }}$, as suggested in previous studies where P adsorption by Fe oxides was reduced in the presence of organic compounds (Yan et al., 2016), but the range of OM content in this study was too narrow (4-9\%) to strongly support this hypothesis.

Colloidal-P binding materials and relationships with soil properties, soil DPS and P sorption parameters vary regarding the size of the colloidal fraction (Missong et al., 2018a). The medium-sized (200-450 nm) colloidal fraction considered in this study does cover a quarter of the entire colloidal fraction (1-1000 nm). Therefore, some colloidal properties such as high specific binding for $\mathrm{P}$ are likely to be much lower in the mediumsized colloidal fraction than in the finer colloidal and nanoparticulate fractions $(<200 \mathrm{~nm})$. Hence, the results here possibly underestimate the complete role of $\mathrm{P}_{\text {coll }}$ in mobilisation processes and further work would be needed to look at the finer colloidal and nanoparticulate fractions in the $<200$ nm range (Missong et al., 2018a; Gottselig et al., 2017).

\subsection{Impact of fertilization practices on medium-sized colloidal phosphorus}

Medium-sized $\mathrm{P}_{\text {coll }}$ mobilisation and soluble P concentrations appeared to be controlled differently regarding the P treatment type (organic, synthetic). Medium-sized $\mathrm{P}_{\text {coll }}$ concentrations were only influenced by the synthetic fertilizer treatment (SF2 only), even at a lower application rate compared to cattle slurry, while $\mathrm{DRP}_{\mathrm{SS}}$ concentrations were increased by both types of treatments. Hence, the cattle slurry treatment did not decrease medium-sized $\mathrm{P}_{\text {coll }}$, as assumed, and had no effect.

The results suggest that application of cattle slurry (and associated organic anions) may reduce the sorption sites available for P by competition, as shown in previous studies (Oburger et al., 2011). However, it may as a consequence increase soil DPS and DRP ${ }_{\text {ss }}$ concentrations (bioavailable) especially in soils with low $\mathrm{S}_{\max }$ and $\mathrm{k}$ as measured in GA-4. Soil DPS appeared to be a key parameter controlling DRP ss $_{\text {concentra- }}$ tions in treated soils and is known to enhance the dispersion of colloid-bound P (Siemens et al., 2004; Ilg et al., 2008). On the other hand, contrasting (increase and decrease) effects of the synthetic fertilizer treatment on medium-sized $\mathrm{RP}_{\text {coll }}$ concentrations (GA-4 and AA-9, respectively) also support the key role of soil DPS. Application of $\mathrm{P}$ to soils with higher DPS may destabilise the previously adsorbed P (this may require further investigation as no significant increase in $\mathrm{DRP}_{\mathrm{ss}}$ was measured) whereas in soils with lower DPS it may promote binding of $\mathrm{P}$ (as suggested by the increase in DPS). 
However, the effect of one single fertilizer application on soluble P and $\mathrm{P}_{\text {coll }}$ doesn't take into account the temporal variation due to several $P$ applications. Parameters such as DPS, $S_{\max }$ and $k$ would likely be modified and be responsible for increasing soluble and $\mathrm{P}_{\text {coll }}$ concentrations. Further work would be needed to assess the temporal changes of P saturation and sorption using multiple $P$ applications and to assess their importance for $\mathrm{P}_{\text {coll }}$ mobilisation over time (existence of a tipping point). Hence, the lack of response for some soils may be related to soils far from $\mathrm{P}$ saturation. Moreover, the significant variation between the sample replicates (especially for medium-sized $U_{\text {coll }}$ ) in treated and untreated soils (especially for GA-4 and AA-9 with the highest mediumsized $\mathrm{P}_{\text {coll }}$ concentrations) indicates the difficulties to precisely assess $\mathrm{P}_{\text {coll }}$ and the limitation of the filtration technique used (Zirkler et al., 2012). However, this still shows the higher potential for medium-sized $\mathrm{P}_{\text {coll }}$ in these soils but can also be responsible for the lack of variation measured between treatment application rates.

\subsection{Implications for losses of soil colloidal phosphorus to transfer pathways to groundwater}

A soil chemical assessment is required to consider the roles of medium-sized $\mathrm{P}_{\text {coll }}$ processes using results from this study. Soil chemical properties as M3-Fe, DPS and $S_{\max }$ are important for mitigating mediumsized $\mathrm{P}_{\text {coll }}$ (which is mainly unreactive $\mathrm{P}$ ) concentrations mobilised in soils and reduce $\mathrm{P}$ losses to GW and surface water. In these water bodies, medium-sized $\mathrm{P}_{\text {coll }}$ can become bioavailable after $\mathrm{P}$ release (Jeanneau et al., 2014; Lambert et al., 2013; Montalvo et al., 2015) and cause ecological issues. However, soil chemical properties can be variable in space and specific soil tests are required to localise critical areas where risks of $\mathrm{P}_{\text {coll }}$ mobilisation are important with an emphasis on metals contents (especially Fe) and DPS. Hence, frequent soil P tests are needed in order to more carefully manage high P soils with more adapted P fertilization types/rates/fractionations. As cattle slurry treatment did not indicate any effect on medium-sized $\mathrm{P}_{\text {coll }}$ concentrations, even at a higher application rate than synthetic fertilizer, use of this type of fertilizer, especially in soils with higher M3-Fe and DPS, would attenuate mediumsized $\mathrm{P}_{\text {coll }}$ that could potentially be mobilised and lost to GW. However, the data here suggest that there is likely to be an increase in $\mathrm{DRP}_{\mathrm{ss}}$, or at least associated with colloids or nanoparticles less than $450 \mathrm{~nm}$. This will require further investigation. These last two points on the association between soil $\mathrm{P}_{\text {coll }}$ and $\mathrm{DRP}_{\mathrm{sS}}$ is important as $\mathrm{P}_{\text {coll }}$ can be readily mobilised and easily lost to $\mathrm{GW}$, i.e. some $\mathrm{P}_{\text {coll }}$ forms may be bioavailable (Van Moorleghem et al., 2013), whereas $\mathrm{DRP}_{\mathrm{ss}}$ is considered directly plant available.

Further to these soil chemistry considerations for mobilisation, $\mathrm{P}_{\text {coll }}$ can be leached to GW via macropores or preferential flow paths (Bol et al., 2016; Julich et al., 2017) especially in grassland catchments that tend to have more macropore pathways (Kramers et al., 2012) and may be enhanced by soil cracking during droughts. Further research is, therefore, required to understand the role of soil physical properties on $\mathrm{P}_{\text {coll }}$ transfer to $\mathrm{GW}$ and, at larger scales, investigations on the role of $\mathrm{P}_{\text {coll }}$ in the delivery of $\mathrm{P}$ to surface water are needed. This will add important insights into the particulate to dissolved $\mathrm{P}$ concentration spectrum in the soil-water environment, including colloids and nanoparticles, to better understand mobilisation and pathways, and their spatial and temporal dynamics.

\section{Conclusion}

This study investigated medium-sized soil $\mathrm{P}_{\text {coll }}(200-450 \mathrm{~nm})$ and soil solution soluble $\mathrm{P}(<450 \mathrm{~nm})$ fractions in contrasting untreated soils and the influence of organic and synthetic fertilizer P treatments to provide a chemical risk assessment of medium-sized $\mathrm{P}_{\text {coll }}$ mobilisation to GW. Soil WDC P and P-binding materials were analysed along with soil solution soluble P. The study highlighted an effect of soil properties on medium-sized soil $\mathrm{P}_{\text {coll }}$ mobilisation and its association with soluble
P. Soil M3-Fe and M3-Al positively influenced medium-sized unreactive and reactive $\mathrm{P}_{\text {coll }}$, respectively. In $\mathrm{P}$ treated soils, application of organic $\mathrm{P}$ had no effect on medium-sized $\mathrm{P}_{\text {coll }}$ even at a higher rate of application than the synthetic fertilizer treatment. However in soils with low P sorption properties, it may increase soil DPS and soluble P, important for plant uptake.

Results of the present study have important implications for localisation of soils with high potential for medium-sized $\mathrm{P}_{\text {coll }}$ (and other colloidal fractions) mobilisation/attenuation. Additional soil parameters should be integrated in soil testing and include metal contents (M3-Fe and M3-Al) and DPS measurements with frequent soil P tests (M3-P). This is especially important for catchments or fields with Cambisol/Podzol soils. Furthermore, the association between soil $\mathrm{P}_{\text {coll }}$ and soil solution $P$ is important and has to be further investigated to optimise plant uptake and reduce environmental risk of P leaching to GW.

\section{CRediT authorship contribution statement}

Maelle Fresne: Conceptualization, Methodology, Validation, Formal analysis, Investigation, Data curation, Writing - original draft, Writing review \& editing, Visualization. Phil Jordan: Conceptualization, Methodology, Writing - review \& editing. Owen Fenton: Conceptualization, Methodology, Writing - review \& editing. Per-Erik Mellander: Conceptualization, Methodology, Resources, Writing - review \& editing, Funding acquisition. Karen Daly: Conceptualization, Methodology, Validation, Resources, Writing - review \& editing, Supervision.

\section{Declaration of competing interest}

The authors declare that they have no known competing financial interests or personal relationships that could have appeared to influence the work reported in this paper.

\section{Acknowledgements}

We thank the ACP land owners and farmers for cooperation and field sampling permission, the ACP staff especially David Ryan and Dermot Leahy for field sampling assistance, Gérard Gruau and Sen Gu from Géosciences Rennes for advices on the colloidal fractions. The authors also thank Denis Brennan, Maria Radford, Linda Moloney-Finn and Brendan Healy for laboratory support and services. The lab assistance of Shane Scannell and Shannon Devereux is greatly appreciated. Funding was provided by the Department of Agriculture, Food and the Marine through the Teagasc Agricultural Catchments Programme and by the Teagasc Walsh Fellowship Programme.

\section{Supplementary informations}

Catchments characteristics are presented in SI 1, soil sampling locations in the study catchments are shown in SI 2, cattle slurry chemical composition is presented in SI 3, and flow chart of the methodology is shown in SI 4. Supplementary informations to this article can be found online at https://doi.org/10.1016/j.scitotenv.2020.142112.

\section{References}

Andersen, J.H., Carstensen, J., Conley, D.J., Dromph, K., Fleming-Lehtinen, V., Gustafsson, B.G., et al., 2017. Long-term temporal and spatial trends in eutrophication status of the Baltic Sea. Biol. Rev. 92, 135-149. https://doi.org/10.1111/brv.12221.

Askew, F.E., 2005. Persulfate method for simultaneous determination of total nitrogen and total phosphorus. 4500-P J. In: Eaton, A.D., Clesceri, L.S., Rice, W.E., Greenberg, A.E. (Eds.), Standard Methods for the Examination of Waters and Wastewater, 21st edition American Public Health Association, 8001 street, NW Washington, DC 2001-3710, pp. 160-161 ISBN 0-87553-047-8

Askew, F.E., Smith, R.K., 2005. Inorganic non metallic constituents; phosphorus; method 4500-P F. Automated ascorbic acid reduction method. In: Eaton, D. A. Clesceri, L.S. Rice, E.W., Greensberg, A.E. (Eds.), Standard Methods for the Examination of Waters and Waste Water. American Public Health Association, 8001 street, NW Washington, DC 2001-3710, pp. 4-155 ISBN 0-87553-047-8. 
Avery, B.W., Bascomb, C.L., 1974. Soil Survey Laboratory Methods: Soil Survey of Great Britain (England and Wales), Harpenden (Rothamsted Experimental Station, Harpenden, Herts.).

Baalousha, M., Kammer, F.V.D., Motelica-Heino, M., Le Coustumer, P., 2005. 3D characterization of natural colloids by FIFFF-MALLS-TEM. Anal. Bioanal. Chem. 383 (4), 549-556. https://doi.org/10.1007/s00216-005-0006-9.

Baird, R.B., 2005. Aggregate organic constituents; Total Organic Carbon (TOC). Method 5310 B high temperature combustion methods. In: Eaton, D.A., Clesceri, L.S., Rice, E.W., Greensberg, A.E. (Eds.), Standard Methods for the Examination of Waters and Waste Water, 21st ed. American Public Health Association, 8001 street, NW Washington, DC 2001-3710, pp. 5-21 ISBN 0-87553-047-8.

Bol, R., Julich, D., Brödlin, D., Siemens, J., Kaiser, K., Dippold, M.A., et al., 2016. Dissolved and colloidal phosphorus fluxes in forest ecosystems-an almost blind spot in ecosystem research. J. Plant Nutr. Soil Sci. 179, 425-438. https://doi.org/ 10.1002/jpln.201600079.

Brady, N.C., Weil, R.R., 2008. The Nature and Properties of Soils. 14th edition. Pearson Education Inc, United States of America.

Bryne, E., 1979. Chemical Analysis of Agricultural Materials. An Foras Taluntais ed, Dublin.

De Boodt, M.F., Hayes, M.H.B., Herbillon, A., 2013. Soil Colloids and Their Associations in Aggregates. Springer Science \& Business Media.

Dupas, R., Gruau, G., Gu, S., Humbert, G., Jaffrézic, A., Gascuel-Odoux, C., 2015. Groundwater control of biogeochemical processes causing phosphorus release from riparian wetlands. Water Res. 84, 307-314. https://doi.org/10.1016/j. watres.2015.07.048.

Dupas, R., Mellander, P.-E., Gascuel-Odoux, C., Fovet, O., McAleer, E.B., McDonald, N.T., et al., 2017. The role of mobilisation and delivery processes on contrasting dissolved nitrogen and phosphorus exports in groundwater fed catchments. Sci. Total Environ. 599-600, 1275-1287. https://doi.org/10.1016/j. scitotenv.2017.05.091.

Ekholm, P., 1994. Bioavailability of phosphorus in agriculturally loaded rivers in southern Finland. Hydrobiologia 287, 179-194. https://doi.org/10.1007/BF00010733.

Environmental Protection Agency, 1996. SW-846 Test Method 3052: Microwave Assisted Acid Digestion of Siliceous and Organically Based Matrices. EPA.

Fealy, R.M., Buckley, C., Mechan, S., Melland, A., Mellander, P.-E., Shortle, G., et al., 2010. The Irish Agricultural Catchments Programme: catchment selection using spatial multicriteria decision analysis. Soil Use Manag. 26, 225-236. https://doi.org/10.1111/ j.1475-2743.2010.00291.x.

Gottler, R.A., Piwoni, M.D., 2005. Metals. Method 3120 B. Inductively coupled plasma (ICP) method. In: Eaton, D.A., Clesceri, L.S., Rice, E.W., Greensberg, A.E. (Eds.), Standard Methods for the Examination of Waters and Waste Water, 21st ed. American Public Health Association, 8001 street, NW Washington, DC 2001-3710, pp. 3-39.

Gottselig, N., Nischwitz, V., Meyn, T., Amelung, W., Bol, R., Halle, C., et al., 2017. Phosphorus binding to nanoparticles and colloids in forest stream waters. Vadose Zone J. 16 (3), 1-12. https://doi.org/10.2136/vzj2016.07.0064.

Heathwaite, L., Haygarth, P., Matthews, R., Preedy, N., Butler, P., 2005. Evaluating colloidal phosphorus delivery to surface waters from diffuse agricultural sources. J. Environ. Qual. 34, 287-298. https://doi.org/10.2134/jeq2005.0287a.

Henderson, R., Kabengi, N., Mantripragada, N., Cabrera, M., Hassan, S., Thompson, A., 2012. Anoxia-induced release of colloid- and nanoparticle-bound phosphorus in grassland soils. Environ. Sci. Technol. 46, 11727-11734. https://doi.org/10.1021/es302395r.

Hongthanat, N., Kovar, J.L., Thompson, M.L., Russell, J.R., Isenhart, T.M., 2016. Phosphorus source-sink relationships of stream sediments in the Rathbun Lake watershed in southern Iowa, USA. Environ. Monit. Assess. 188 (8), 453. https://doi.org/10.1007 s10661-016-5437-6.

Ilg, K., Siemens, J., Kaupenjohann, M., 2005. Colloidal and dissolved phosphorus in sandy soils as affected by phosphorus saturation. J. Environ. Qual. 34, 926-935. https://doi. org/10.2134/jeq2004.0101.

Ilg, K., Dominik, P., Kaupenjohann, M., Siemens, J., 2008. Phosphorus-induced mobilization of colloids: model systems and soils. Eur. J. Soil Sci. 59, 233-246. https://doi. org/10.1111/j.1365-2389.2007.00982.x.

Jarvie, H.P., Sharpley, A.N., Brahana, V., Simmons, T., Price, A., Neal, C., et al., 2014. Phosphorus retention and remobilization along hydrological pathways in karst terrain. Environ. Sci. Technol. 48 (9), 4860-4868. https://doi.org/10.1021/es405585b.

Jeanneau, L., Jaffrezic, A., Pierson-Wickmann, A.-C., Gruau, G., Lambert, T., Petitjean, P., 2014. Constraints on the sources and production mechanisms of dissolved organic matter in soils from molecular biomarkers. Vadose Zone J. 13 (7). https://doi.org/ 10.2136/vzj2014.02.0015.

Jiang, X., Bol, R., Nischwitz, V., Siebers, N., Willbold, S., Vereecken, H., et al., 2015. Phosphorus containing water dispersible nanoparticles in arable soil. J. Environ. Qual. 44 (6), 1772-1781. https://doi.org/10.2134/jeq2015.02.0085.

Jiang, C., Sequaris, J.-M., Vereecken, H., Klumpp, E., 2013. Diffusion-controlled mobilization of water-dispersible colloids from three German silt loam topsoils: effect of temperature. Eur. J. Soil Sci. 64, 777-786. https://doi.org/10.1111/ejss.12086.

Jiang, C., Séquaris, J.-M., Vereecken, H., Klumpp, E., 2017. Effects of temperature and associated organic carbon on the fractionation of water-dispersible colloids from three silt loam topsoils under different land use. Geoderma 299, 43-53. https://doi.org/ 10.1016/j.geoderma.2017.03.009.

Julich, D., Julich, S., Feger, K., 2017. Phosphorus fractions in preferential flow pathways and soil matrix in hillslope soils in the Thuringian Forest (Central Germany). J. Plant Nutr. Soil Sci. 180, 407-417. https://doi.org/10.1002/jpln.201600305.

Kovar, J.L., Pierzynski, G.M., 2009. Methods of Phosphorus Analysis for Soils, Sediments, Residuals, and Waters. Second edition. Virginia Tech University.

Kramers, G., Holden, N.M., Brennan, F., Green, S., Richards, K.G., 2012. Water content and soil type effects on accelerated leaching after slurry application. Vadose Zone J. 11 (1). https://doi.org/10.2136/vzj2011.0059.
Lambert, T., Pierson-Wickmann, A.-C., Gruau, G., Jaffrezic, A., Petitjean, P., Thibault, J., et al. 2013. Hydrologically driven seasonal changes in the sources and production mechanisms of dissolved organic carbon in a small lowland catchment. Water Resour. Res. 49, 5792-5803. https://doi.org/10.1002/wrcr.20466.

Liu, J., Yang, J., Liang, X., Zhao, Y., Cade-Menun, B.J., Hu, Y., 2014. Molecular speciation of phosphorus present in readily dispersible colloids from agricultural soils. Soil Sci. Soc. Am. J. 78 (1), 47-53. https://doi.org/10.2136/sssaj2013.05.0159.

Mehlich, A., 1984. Mehlich-3 soil test extractant - a modification of Mehlich-2 extractant Commun. Soil Sci. Plant Anal. 15, 1409-1416.

Mellander, P.-E., Jordan, P., Shore, M., Melland, A.R., Shortle, G., 2015. Flow paths and phosphorus transfer pathways in two agricultural streams with contrasting flow controls. Hydrol. Process. 29, 3504-3518. https://doi.org/10.1002/ hyp. 10415.

Mellander, P.-E., Jordan, P., Shore, M., McDonald, N.T., Wall, D.P., Shortle, G., et al., 2016 Identifying contrasting influences and surface water signals for specific groundwater phosphorus vulnerability. Sci. Total Environ. 541, 292-302. https://doi.org/10.1016/j. scitotenv.2015.09.082.

Missong, A., Bol, R., Nischwitz, V., Krüger, J., Lang, F., Siemens, J., Klumpp, E., 2018a. Phosphorus in water dispersible-colloids of forest soil profiles. Plant Soil 427, 71-78. https://doi.org/10.1007/s11104-017-3430-7.

Missong, A., Bol, R., Willbold, S., Siemens, J., Klumpp, E., 2016. Phosphorus forms in forest soil colloids as revealed by liquid-state 31P-NMR. J. Plant Nutr. Soil Sci. 179, 159-167. https://doi.org/10.1002/jpln.201500119.

Missong, A., Holzmann, S., Bol, R., Nischwitz, V., Puhlmann, H., v. Wilpert, K., Siemens, J., Klumpp, E., 2018b. Leaching of natural colloids from forest topsoils and their relevance for phosphorus mobility. Sci. Total Environ. 634, 305-315. https://doi.org/ 10.1016/j.scitotenv.2018.03.265.

Mohanty, S.K., Saiers, J.E., Ryan, J.N., 2015. Colloid mobilization in a fractured soil during dry-wet cycles: role of drying duration and flow path permeability. Environ. Sci. Technol. 49, 9100-9106. https://doi.org/10.1021/acs.est.5b00889.

Montalvo, D., Degryse, F., McLaughlin, M.J., 2015. Natural colloidal P and its contribution to plant P uptake. Environ. Sci. Technol. 49 (6), 3427-3434. https://doi.org/10.1021/ es504643f.

Némery, J., Garnier, J., 2016. The fate of phosphorus. Nature 29, 343-344. https://doi.org/ $10.1038 /$ ngeo2702

Oburger, E., Jones, D.L., Wenzel, W.W., 2011. Phosphorus saturation and pH differentially regulate the efficiency of organic acid anion-mediated P solubilization mechanisms in soil. Plant Soil 341, 363-382. https://doi.org/10.1007/s11104010-0650-5.

O’Flynn, C.J., Fenton, O., Wall, D.P., Brennan, R.B., McLaughlin, M.J., Healy, M.G., 2018. Influence of soil phosphorus status, texture, $\mathrm{pH}$ and metal content on the efficacy of amendments to pig slurry in reducing phosphorus losses. Soil Use Manag. 34, 1-8 https://doi.org/10.1111/sum.12391.

Pautler, M., Sims, J., 2000. Relationships between soil test phosphorus, soluble phosphorus, and phosphorus saturation in Delaware soils. Soil Sci. Soc. Am. J. 64, 765-773. https://doi.org/10.2136/sssaj2000.642765x.

Rieckh, H., Gerke, H.H., Glæsner, N., Kjaergaard, C., 2015. Tracer, dissolved organic carbon, and colloid leaching from erosion-affected arable hillslope soils. Vadose Zone J. 14 (12), 1539-1663. https://doi.org/10.2136/vzj2015.08.0110.

Rousseau, M., Di Pietro, L., Angulo-Jaramillo, R., Tessier, D., Cabibel, B., 2004. Preferential transport of soil colloidal particles: physicochemical effects on particle mobilization. Vadose Zone J. 3 (1), 247-261. https://doi.org/10.2136/vzj2004.2470.

Sarker, A., Kashem, M., Osman, K., Hossain, I., Ahmed, F., 2014. Evaluation of available phosphorus by soil test methods in an acidic soil incubated with different levels of lime and phosphorus. Open J. Soil Sci. 4, 103-108. https://doi.org/10.4236/ ojss.2014.43014.

Schelde, K., de Jonge, L.W., Kjaergaard, C., Laegdsmand, M., Rubæk, G.H., 2006. Effects of manure application and plowing on transport of colloids and phosphorus to tile drains. Vadose Zone J. 5 (1), 445-458. https://doi.org/10.2136/vzj2005.0051.

Séquaris, J., Klumpp, E., Vereecken, H., 2013. Colloidal properties and potential release of water-dispersible colloids in an agricultural soil depth profile. Geoderma 193-194, 94-101. https://doi.org/10.1016/j.geoderma.2012.10.014.

Shortle, G., Jordan, P., 2017. Agricultural Catchments Programme Phase 2 Report. Teagasc Crops, Environment and Land Use Programme. Johnstown Castle Environment Research Centre, Wexford, p. 287.

Siemens, J., Ilg, K., Lang, F., Kaupenjohann, M., 2004. Adsorption controls mobilization of colloids and leaching of dissolved phosphorus. Eur. J. Soil Sci. 55, 253-263. https:// doi.org/10.1046/j.1365-2389.2004.00596.x.

Storer, D.A., 1984. A simple high sample volume ashing procedure for determination of soil organic-matter. Commun. Soil Sci. Plant Anal. 15, 759-772. https://doi.org/ 10.1080/00103628409367515.

Turner, B.L., Cade-Menun, B.J., Condron, L.M., Newman, S., 2005. Extraction of soil organic phosphorus. Talanta 66, 294-306. https://doi.org/10.1016/j.talanta.2004.11.012.

Van Moorleghem, C., De Schutter, N., Smolders, E., Merckx, R., 2013. The bioavailability of colloidal and dissolved organic phosphorus to the alga Pseudokirchneriella subcapitata in relation to analytical phosphorus measurements. Hydrobiologia 709 (1), 41-53. https://doi.org/10.1007/s10750-013-1442-8.

Van Moorleghem, C., Six, L., Degryse, F., Smolders, E., Merckx, R., 2011. Effect of organic P forms and $\mathrm{P}$ present in inorganic colloids on the determination of dissolved $\mathrm{P}$ in environmental samples by the diffusive gradient in thin films technique, ion chromatography, and colorimetry. Anal. Chem. 83, 5317-5323. https://doi.org/10.1021/ ac200748e.

Wall, D.P., Murphy, P.N.C., Melland, A.R., Mechan, S., Shine, O., Buckley, C., et al., 2012 Evaluating nutrient source regulations at different scales in five agricultural catchments. Environ. Sci. Pol. 24, 34-43. https://doi.org/10.1016/j.envsci.2012.06.007. 
Withers, P.J.A., Jordan, P., May, L., Jarvie, H.P., Deal, N.E., 2014. Do septic tank systems pose a hidden threat to water quality? Front. Ecol. Environ. 12, 123-130. https://doi.org/ $10.1890 / 130131$.

Yan, J., Jiang, T., Yao, Y., Lu, S., Wang, Q., Wei, S., 2016. Preliminary investigation of phosphorus adsorption onto two types of iron oxide-organic matter complexes. J. Environ. Sci. 42, 152-162. https://doi.org/10.1016/j.jes.2015.08.008.
Zhang, M., He, Z., Calvert, D., Stoffella, P., 2003. Colloidal iron oxide transport in sandy soil induced by excessive phosphorus application. Soil Sci. 168, 617-626. https://doi.org/ 10.1097/01.ss.0000090802.06903.bc.

Zirkler, D., Lang, F., Kaupenjohann, M., 2012. "Lost in filtration" - the separation of soil colloids from larger particles. Colloids Surf. A Physicochem. Eng. Asp. 399, 35-40. https://doi.org/10.1016/j.colsurfa.2012.02.021. 